\title{
Changes in Mean Level and Stability of Arterial Blood Pressure after Bilateral Sectioning of the Carotid Sinus Nerves in Conscious Rabbits
}

\author{
Shin-ichiro Katsuda, Noriji Taba and Hiroshi Hosomi* \\ Department of Animal Physiology, Kobe University \\ School of Agriculture, Kobe-shi 657 \\ * Department of Physiology, Kagawa Medical School, \\ Miki-cho, Kagawa-ken 761-07
}

(Received November 19, 1986)

\begin{abstract}
Key Words : Conscious rabbit, mean arterial blood pressure, bilateral carotid sinus denervation
\end{abstract}

$\mathrm{We}^{1)}$ previously reported the mean level and variability of mean arterial blood pressure (MAP) for $6 \mathrm{hrs}$ in unanesthetized rabbits. The variability of MAP was significantly small, if MAP was in the normotensive range. This suggest that the carotid sinus and aortic arch baroreflex systems might powerfully control arterial blood pressure (AP) in a normotensive state. However, there are quantitative differences in responsiveness of the carotid sinus and aortic arch baroreceptors. The carotid sinus baroreceptor responds to change in AP above $50-60 \mathrm{mmHg}$ and functions most powerfully at around $100 \mathrm{mmHg}^{2,5)}$. The aortic arch baroreceptor initiates to respond to AP above $80-90 \mathrm{mmHg}$ and operates most strongly at $120-160 \mathrm{mmHg}^{2-5}$. In a normotensive state, the carotid sinus baroreceptor is considered to contribute much to regulation of $\mathrm{AP}$ in comparison with the aortic arch baroreceptor. If the carotid sinus baroreflex does not function, AP could become unstable.

In the present study, effects of bilateral sectioning of the carotid sinus nerves on mean level and stability of MAP were examined in conscious rabbits. MAP recordings for $6 \mathrm{hrs}$ were performed before and after sectioning the carotid sinus nerves. Mean value and standard deviation of MAP in carotid sinus denervated rabbits were compared with those in intact rabbits.

\section{Materials and Methods}

The surgical procedure for catheterization and the experimental conditions were

頸動脈洞神経切断による意識下ウサギの血圧およびその安定性の変化：勝田新一郎・田場典治・細見 弘 ${ }^{1}$ (神戸大学農学部 神戸市 657 , 香川医科大学 香川県三木町 761-07 ${ }^{1}$ ) 


\section{Blood Pressure after Carotid Sinus Denervation}

similar to those reported previously ${ }^{1)}$. Five Japanese white rabbits of either sex (3.0 to $3.6 \mathrm{~kg}$ and aged 6 to 12 months) were anesthetized by an intravenous injection of pentobarbital sodium in a dose of $20.0 \mathrm{mg} / \mathrm{kg}$. A large bore catheter was chronically implanted into the aortic arch via the left subclavian artery and filled with heparin (500 unit). A few days after the catheterization, the rabbits were confirmed to be fully conscious and active and used for AP recording. AP was monitored with a catheter-transducer system. MAP derived from AP using a low-pass filter with a time constant of $2 \mathrm{sec}$, was fed into a digital computer every second for $6 \mathrm{hrs}$ from about 10 a.m. to 4 p.m. through an analogue-to-digital converter. After all the rabbits were used for MAP recording under intact conditions, they were anesthetized again with pentobarbital sodium $(15.0 \mathrm{mg} / \mathrm{kg})$ and sectioned the bilateral carotid sinus nerves. Three to five days were allowed to recover from anesthesia and the surgery. MAP was recorded again under the same experimental conditions as those in the intact rabbit.

\section{Results and Discussion}

Mean (M) and standard deviation (SD), calculated from each successive MAP record for $6 \mathrm{hrs}$ before and after bilateral sectioning of the carotid sinus nerves, were shown in Table 1. Mean $\left(\mathrm{M}_{\text {int }}\right)$ and standard deviation $\left(\mathrm{SD}_{\text {int }}\right)$ of MAP in the intact rabbit ranges from 78.6 to $96.3 \mathrm{mmHg}$ (mean $\pm \mathrm{SE}, 88.6 \pm 2.7 \mathrm{mmHg}$ ) and from 6.1 to $9.7 \mathrm{mmHg}$ (mean, $7.4 \mathrm{mmHg}$ ), respectively. After severing the carotid sinus nerves, an elevation of MAP and an increase in variation of MAP were observed in each rabbit. Mean $\left(\mathrm{M}_{\mathrm{cs}}\right)$ and standard deviation $\left(\mathrm{SD}_{\mathrm{cs}}\right)$ of $\mathrm{MAP}$ in the carotid sinus denervated rabbit varied from 93.3 to $105.1 \mathrm{mmHg}$ (mean $\pm \mathrm{SE}, 100.8 \pm 2.0 \mathrm{mmHg}$ ) and from 8.1 to $10.8 \mathrm{mmHg}$ (mean, $9.4 \mathrm{mmHg}$ ), respectively. The $M_{c s}$ was significantly larger than the $M_{\text {int }}\left(p<0.05\right.$, Wilcoxon matched pair rank test). The $S_{c s}$ was also significantly large in comparison with the $\mathrm{SD}_{\mathrm{int}}(\mathrm{p}<0.05$, Wilcoxon matched

Table 1. Changes in mean and standard deviation of MAP for $6 \mathrm{hrs}$ after bilateral sectioning of the carotid sinus nerves.

\begin{tabular}{ccccccc}
\hline $\begin{array}{c}\text { Rabbit } \\
\text { No. }\end{array}$ & Sex & $\begin{array}{c}\text { B.W. } \\
(\mathbf{k g})\end{array}$ & $\begin{array}{c}\mathrm{M}_{\mathrm{int}} \\
(\mathrm{mmHg})\end{array}$ & $\begin{array}{c}\mathrm{SD}_{\mathrm{int}} \\
(\mathrm{mmHg})\end{array}$ & $\begin{array}{c}\mathrm{M}_{\mathrm{cs}} \\
(\mathrm{mmHg})\end{array}$ & $\begin{array}{c}\mathrm{SD}_{\mathrm{cs}} \\
(\mathrm{mmHg})\end{array}$ \\
\hline 1 & F & 3.6 & 86.2 & 6.1 & 102.0 & 8.1 \\
2 & $\mathrm{~F}$ & 3.0 & 88.4 & 7.9 & 105.0 & 9.5 \\
3 & $\mathrm{M}$ & 3.3 & 93.3 & 9.7 & 98.9 & 10.8 \\
4 & $\mathrm{M}$ & 3.1 & 78.6 & 6.8 & 93.3 & 9.7 \\
5 & $\mathrm{~F}$ & 3.0 & 96.3 & 6.5 & 105.1 & 8.9 \\
Mean & $/$ & 3.2 & 88.6 & 7.4 & 100.8 & 9.4 \\
\pm SE & $/$ & 0.1 & 2.7 & $/$ & 2.0 & $/$ \\
\hline
\end{tabular}

F: Female, M: Male, B.W.: Body weight. $\mathrm{M}_{\text {int }}$ and $\mathrm{SD}_{\mathrm{int}}$ represent mean and standard deviation of MAP for $6 \mathrm{hrs}$ in the intact rabbit, respectively. $\mathrm{M}_{\mathrm{CS}}$ and $\mathrm{SD}_{\mathrm{CS}}$ represent mean and standard deviation of MAP for $6 \mathrm{hrs}$ in the denervated rabbit, respectively. 
pair rank test).

$\mathrm{SD}$ is one index of variability of AP. Increase or decrease in SD has been employed for estimation of control ability of the arterial pressure control system ${ }^{1,6-8)}$. In the present study, the increase in the SD means that the overall control ability of the baroreflex system was decreased by sectioning of the carotid sinus nerves. HosomI et al. . $^{9}$ reported that bilateral sectioning of the carotid sinus nerves decreased the open-loop gain of the rapidly acting arterial pressure control system by about $59.5 \%$ in the anesthetized rabbit. According to the control theory ${ }^{9-11}$, a decrease in the open-loop gain results in a decrease in capacity of homeostasis, i.e., a decrease in stability, and causes in an increase in variation of the controlled value, that is, arterial pressure. Therefore, the variation of MAP (SD) should be estimated about $15 \mathrm{mmHg}$. In the present study, the $\mathrm{SD}$ was $9.4 \mathrm{mmHg}$ after sectioning the carotid sinus nerves. This difference may depend on a compensatory increase in pressure control ability of the remaining baroreflex systems, i.e., the aortic arch and cardiopulmonary baroreflex systems. The other possible reason may be that the aortic arch baroreflex system operated near its optimum range, since MAP increased from 88.6 to $100.8 \mathrm{mmHg}$ after sectioning the carotid sinus nerves.

\section{References}

1) Katsuda, S., N. Taba and H. Hosomi, Jpn. J. Zootech. Sci., $56: 954-961.1985$.

2) Donald, D.E. and A.J. Edis, J. Physiol., $215: 521-538.1971$.

3) Allison, J.L., K. Sagawa and M. Kumada, Am. J. Physiol., 217 : 1576-1584. 1969.

4) Edis, A.J., Am. J. Physiol., 221 : 1352-1357. 1971.

5) Pelletier, C.L,, D.L. Clement and J.T. Shepherd, Circ. Res., $31: 557-568.1972$.

6) Cowley, A.M., J.F. Liard and A.C. Guyton, Circ. Res., 32:564-576. 1973.

7) I то, C.S. and A.M. SCHER, Circ. Res., 42:230-236. 1978.

8) 'Ito, C.S. and A.M. SCHER, Circ. Res., $45: 26-34.1979$.

9) Hosomi, H., S. Katsuda, H. Morita, Y. Nishida and S. Koyama, Am. J. Physiol., $250:$ H944-H953. 1986.

10) MilhoRn, H.T. Jr., The Application of Control Theory to Physiological Systems. 156-166. B.W. Saunders. Philadelphia, 1966.

11) Hosomi, H. and K. Yokoyama, Am. J. Physiol., 240:H832-H836. 1981. 